\title{
Agility in public sector IT projects
}

\author{
Maria Dietel \\ University of Potsdam \\ August.-Bebel-Str. 89, 14482 Potsdam \\ Germany \\ mdietel@uni-potsdam.de
}

\author{
Moreen Heine \\ University of Lübeck \\ Ratzeburger Allee 160, 23562 Lübeck \\ Germany \\ heine@imis.uni-luebeck.de
}

\begin{abstract}
Agile methods are increasingly finding their way into public administrations, especially in IT projects. There is also an increasing amount of research. However, the theoretical foundations of the bureaucratic principles are hardly considered. This paper systematically contrasts the characteristics of agile project management methods with bureaucratic principles. Conflicts are presented and options for practice are explained. An analytical framework is developed, which can also be the basis for empirical research.
\end{abstract}

\section{CCS CONCEPTS}

- Applied computing $\rightarrow$ Computers in other domains $\rightarrow$ Computing in government $\rightarrow$ E-government

\section{KEYWORDS}

IT Projects, Bureaucracy, New Public Governance, Agile Project Management

\section{ACM Reference format:}

Maria Dietel, Moreen Heine. 2020. Agility in public sector IT projects. In Proceedings of the $13^{\text {th }}$ International Conference on Theory and Practice of Electronic Governance (ICEGOV 2020), 23-25 September 2020, Athens, Greece, 4 pages. https://doi.org/10.1145/3428502.3428625

\section{INTRODUCTION}

In the period from 2011 to 2015, 24 percent of government IT projects worldwide failed and 55 percent of projects were not implemented within the agreed time, cost or scope [1]. After completion of a project, there are also deficits in the actual acceptance and application by the users (cf. for example [2]). Studies have shown that projects that are processed agilely have a success rate four times higher than projects that are processed with the traditional waterfall model [1]. In view of the problems identified, this raises several questions: How does agile action have a positive influence on the management of a project and how can this action be applied in the public sector and what are the obstacles to its application?

\section{APPROACH}

The applicability of agile methods in the public sector is certainly being investigated in research ([3], [4] and [5]), but this is not theory-driven. In particular, the intrinsic organisational structures of an administration can provide information on how agile project management can be applied in the public sector and where obstacles can be expected. Especially the Weberian administration type with the constitutive features of a bureaucracy offers the possibility to derive the applicability as well as obstacles for the implementation of agile process models ex ante from theory.

Therefore, this paper deals with the ideal type of bureaucracy according to Weber and the reform approaches New Public Management and New Public Governance. The latter addresses the opening of the public sector to the agile methods of the private sector. The paper shows, guided by theory, to what extent agile methods are suitable for bureaucratic organizations. An analytical framework will be developed that derives from the characteristics of agile project management on the one hand and from the characteristics of Weber's ideal bureaucracy model on the other. It forms the basis for empirical studies as well as direct implications for the practical application of agile methods in public sector IT projects.

\section{BACKGROUND}

Projects are distinguished in particular by their unique and innovative character. In return, public administration is characterised by the Weberian type of administration (cf. [6]), which among other things is characterised by highly structured processes in line activities, a strong division of labour combined with specialisation, fixed communication channels and hierarchy. 
Projects in public administration therefore often encounter an insufficiently project-oriented environment [7]. In this section, the contents of traditional and agile project management are covered to highlight the differences between these procedural models. In addition, the fundamentals of Weberian bureaucracy and relevant reform approaches are presented.

\subsection{Agile Project Management in Public Administrations}

Traditional project management is based on a plan-driven project flow. At the beginning, scope, time and cost-related goals are defined and plans for their achievement are drawn up. During the control phase, the plans are implemented and deviations from the plan are minimised [8]. However, agile project management assumes that the project life cycle cannot be predicted with sufficient accuracy at the beginning of the project and that its representation in plans is therefore not promising [8]. A comparison of the magic target triangle illustrates the different approaches (Figure 1). The term agile shows that project management is dynamic and flexible in order to implement changes quickly.

\begin{tabular}{|lccc|}
\multicolumn{1}{c}{ Traditional } & \multicolumn{2}{c}{ Agile } \\
\hline Fixed & Quality/Performance/Scope & Cost & Time \\
\hline & & Value driven \\
Plan driven & & \\
\hline Estimated & Cost & Time & Quality/Performance/Scope \\
\hline
\end{tabular}

Figure 1: The magic target triangle - traditional and agile variant [8]

The existing literature, which considers project management and the public sector together, refers in particular to the application of traditional project management. Mergel points out: "The development, management, and operation of IT projects in government traditionally follow a waterfall approach" [9].

However, agile project management is also finding its way into the public sector. This is demonstrated by strategy papers and practical projects (e.g. Danish Ministry of Economic Affairs, Ministry of Culture and Sport in Spain and British Government ICT Strategy), but also by the current growth of research literature. The practical perspective shows that agile projects in the public ministerial administration can be used fruitfully to achieve good results in the implementation of IT projects [10]. However, the use of agile project management methods can quickly reach its limits in public administration. This concerns budget planning, tendering obligations, risk management and reporting [11]. Even for short project durations, iterative methods generate many decision points, which can easily overstretch the ability of public administrations as contracting authorities to control progress [12]. A valuable contribution to the application of agile project management in the public sector is provided by
Nuottila et al., investigating obstacles to the introduction of agile project management methods in a public authority in Finland [13].

On the one hand, there are positions that agile methods do face some challenges due to the characteristics of the public sector (e.g. [11], [12] and [13]). On the other hand, there are papers that show that at least agile elements can be used successfully, even if obstacles are identified (e.g. [5] and [10]). What much of the work has in common is that the applicability of agile project management and the obstacles in implementation are hardly theoretically substantiated.

\subsection{Weberian Bureaucracy and Reform Approaches}

Obstacles to the use of agile methods were outlined in the previous section. In order to shed theoretical light on the origin of these obstacles and to derive them systematically in the next step, the ideal type of bureaucracy according to Weber will first be presented.

Weber's bureaucracy model is based on the basic principle of rationalism, i.e. predictability, impersonality and objectivity. Bureaucracies are characterized by the following constitutive features [14]:

a) Division of labour and power of command (defined area of responsibility with necessary decision-making powers)

b) Hierarchy (strict system of superordination and subordination)

c) Rule of conduct (fulfilment of tasks and communication procedures according to written technical standards and rules)

d) Administration records (all procedures must be recorded and documented in writing)

Of course, public administrations have not remained statically within this ideal type. The use of project groups relaxes the vertical principle of hierarchy and is supplemented by mechanisms of horizontal cooperation and coordination [15]. Since the 1970s the public administration has been marked by a wide variety of reform waves [16], "which result in a weakening of bureaucratic principles" [15]. With the emergence of more complex tasks and VUCA environments (volatility, uncertainty, complexity, ambiguity), an adaptation of the public sector is thus visible.

The public sector responded to the increased complex challenges by introducing administrative modernisation and reform efforts, discussed under the terms New Public Management (NPM) and New Public Governance (NPG), into public administration since the 1980s. Many managers in public administration face the complex challenges with appropriate management measures, including traditional project management under the NPM and agile project management under the NPG.

The New Public Governance concept promises value-based "good governance" and aims to achieve overall control of social development involving various social actors [17]. Governance 
thus refers to the forms of institutional control beyond the hierarchy and also beyond the market. Governance is characterised by social coordination of action involving civil society actors and decisions are negotiated in networks. Thus, citizens are not passive recipients of services, but active codesigners within a service-oriented administration.

The reform measures described are within the framework of traditional bureaucratic models. In this paper it is assumed that this predominant administrative concept in particular limits the applicability of agile project work in public administrations. Nevertheless, the reform waves NPM and NPG have led to the introduction of management models from the private sector, including project management, and agile procedures in public administrations.

\section{RESULTS}

Table 1 shows the characteristics of traditional and agile project management methods and an overview of the compatibility of agile methods with bureaucratic principles (Cf. list in section 3.2). The comparison categories describe the main differences between the two approaches [18]. For reasons of space, the analysis and presentation of compatibility with traditional methods is dispensed with. With regard to hybrid project management methods, however, such an analysis would be worthwhile.

Table 1: Analytical framework - Agile project management (PM) methods and bureaucratic principles (BP)

\begin{tabular}{|c|c|c|c|}
\hline & $\begin{array}{l}\text { Traditional } \\
\text { PM }\end{array}$ & Agile PM & $\begin{array}{c}\text { Agile PM } \\
\text { and BP (key } \\
\text { conflicts) }\end{array}$ \\
\hline $\begin{array}{l}\text { Fundamental } \\
\text { assumption } \\
\text { and } \\
\text { development } \\
\text { Model }\end{array}$ & $\begin{array}{l}\text { Complete } \\
\text { specifi- } \\
\text { cations and } \\
\text { extensive } \\
\text { planning } \\
\text { (waterfall or } \\
\text { spiral) }\end{array}$ & $\begin{array}{l}\text { Continuous } \\
\text { design and } \\
\text { rapid } \\
\text { feedback } \\
\text { (evolution- } \\
\text { ary } \\
\text { delivery) }\end{array}$ & $\begin{array}{l}\text { b) Over- } \\
\text { straining } \\
\text { the } \\
\text { hierarchical } \\
\text { structure }\end{array}$ \\
\hline $\begin{array}{l}\text { Management } \\
\text { Style }\end{array}$ & $\begin{array}{l}\text { Command } \\
\text { and control }\end{array}$ & $\begin{array}{l}\text { Leadership } \\
\text { and collabo- } \\
\text { ration }\end{array}$ & $\begin{array}{c}\text { a) } \\
\text { Interdisci- } \\
\text { plinary } \\
\text { teams }\end{array}$ \\
\hline $\begin{array}{c}\text { Knowlegde } \\
\text { Management }\end{array}$ & Explicit & Tacit & $\begin{array}{l}\text { d) Written } \\
\text { document- } \\
\text { tation }\end{array}$ \\
\hline $\begin{array}{l}\text { Communi- } \\
\text { cation }\end{array}$ & Formal & Informal & $\begin{array}{l}\text { c) Rule- } \\
\text { compliant } \\
\text { communi- } \\
\text { cation }\end{array}$ \\
\hline $\begin{array}{l}\text { Organisational } \\
\text { Structure }\end{array}$ & Mechanistic & Organic & $\begin{array}{l}\text { a) and b) } \\
\text { Congruent } \\
\text { to mecha- } \\
\text { nistic base }\end{array}$ \\
\hline Quality Control & $\begin{array}{l}\text { Heavy } \\
\text { planning, } \\
\text { strict }\end{array}$ & $\begin{array}{l}\text { Continuous } \\
\text { control and } \\
\text { testing }\end{array}$ & $\begin{array}{l}\text { b) Over- } \\
\text { straining } \\
\text { the }\end{array}$ \\
\hline
\end{tabular}

\begin{tabular}{|c|c|c|}
\hline & $\begin{array}{c}\text { control, late } \\
\text { and heavy } \\
\text { testing }\end{array}$ & $\begin{array}{c}\text { hierarchical } \\
\text { structure }\end{array}$ \\
\hline
\end{tabular}

It is certainly possible to identify further conflicts that would lead to a network of theory-driven contradictions and dependencies. In this article we focus on the most conspicuous conflicts. The following theses are derived from the analytical framework and are to be tested in empirical studies.

1) The division of labour and the predominance of command in the public sector hinder agile project management.

On the one hand, this is due to the necessary interdisciplinarity in agile project teams and the particular emphasis on the individual (see agile values). On the other hand, there is the strict specialisation, which is determined by the professional qualification of the public administration employees.

2) The hierarchy of public authorities is difficult to reconcile with the agile way in which projects are handled.

The principle of superiority and subordination with clear authority of command and strictly regulated service and communication channels is not acceptable in independent, interdisciplinary agile project teams. In addition, the agile distribution of specific roles (e.g. Scrum Master, Product Owner and Project Team) creates new role allocations that diametrically oppose the classic authority to issue directives and also the official channels of public administration.

3) The principles of office hierarchy and command contradict the iterative processing of the project in project groups, generating frequent decision points that need to be processed quickly within Sprint Plannings and Sprint Reviews in order not to jeopardize project processing.

For smooth agile project processing in iterations in the public sector, the decision-making authority must therefore either be integrated into the project work or a member of the public administration must have supreme authority in the sense of a hierarchical power of attorney.

4) In the public sector, the predominant rule-based approach with fixed communication channels reaches its limits in agile project processing (rule-based approach).

Following an ex ante defined project plan, according to the waterfall methodology, would correspond to the principle of rule binding. However, agile project management does not follow written rules and standards. No comprehensive project plans are drawn up ex ante. In addition, the agile approach does not provide for fixed communication channels, but fixed deadlines for 
dialogue. These dialogues are held on a non-hierarchical basis, but with the necessary decision-making authority.

5) The principle of writing in files, which prevails in the public sector, is an obstacle to agile project processing (compliance with documents).

Written project plans and their sub-plans are common in the waterfall procedure which the public sector has long followed. This written nature of all processes and communication is diametrically opposed to the reduced documentation obligations in agile project management. This is also demonstrated by the agile principle "working software over comprehensive documentation".

In addition, further theses can be derived which are based on sets of rules which have arisen on the basis of bureaucratic principles. Restrictions are to be expected, for example, in the context of the invitation to tender (clear description of services in the sense of comparability of offers, pricing) and budget planning (with binding effect). In this article we focus on the fundamental principles of bureaucracy.

\section{CONCLUSIONS}

Practitioners and researchers increasingly and emphatically demand adaptive, forward-looking and agile approaches in IT projects with a holistic focus on human and client-oriented design, which is achieved through shorter development cycles [9]. On the other hand, there are research contributions that consider agile methods and bureaucracy to be on the whole incompatible. The developed theory-based analytical framework shows that a per se negation of the applicability of agile process models is not tenable due to the Weberian administrative tradition. Agile project management can be used in the predominant categories of management in the public sector. If the applicability is restricted, a hybrid approach can be used in the public sector. This guarantees flexible, fast and user-oriented work, which tends to achieve better project results. The analysis framework provides the basis for operationalization, for example in the form of interview questions. When applying the analysis framework for case studies, it should be considered that Weber's theory of the bureaucracy model is an ideal type. The ideal type captures sections of reality that are particularly highlighted. Other aspects, on the other hand, are exaggerated.

In addition to these results, however, there was also a clear need for research into the applicability of agile methods in the public sector. The literature discussion already pointed to this research gap. Comparative studies on the basis of the analytical framework can make a valuable contribution to theory-oriented empirical research. This paper examines the agile approach in general. The agile implementation in specific settings, e.g. in client contractor projects or in projects carried out entirely within the public sector, should also be examined. In addition, it could be investigated how agile procedures can be used across administrative boundaries, e.g. in the context of departmental coordination.

\section{REFERENCES}

[1] Standish Group. 2015. CHAOS Report 2015. Retrieved 2015 from https://www.standishgroup.com/sample_research_files/CHAOSReport2015Final.pdf

[2] Sinawong Sang and Jeong-Dong Lee. 2009. A conceptual model of egovernment acceptance in public sector. Third International Conference on Digital Society. IEEE. 71-76. DOI: https://doi.org/10.1109/ICDS.2009.30

[3] Afonso Ribeiro and Luisa Domingues. 2018. Acceptance of an agile methodology in the public sector. Procedia computer science, 138, 621-629. DOI: https://doi.org/10.1016/j.procs.2018.10.083

[4] Juhani Iivari and Netta Iivari. 2010. Organizational culture and the deployment of agile methods: The competing values model view. Agile Software Development. Springer. Berlin, Heidelberg. 203-222. DOI: https://doi.org/10.1007/978-3-642-12575-1_10

[5] Isaque Vacari and Rafael Prikladnicki. 2015. Adopting agile methods in the public sector: a systematic literature review. Embrapa Informática Agropecuária-Artigo em anais de congresso (ALICE): INTERNATIONAL CONFERENCE ON SOFTWARE ENGINEERING AND KNOWLEDGE ENGINEERING, 27, Pittsburgh. Pittsburgh University. DOI: https://doi.org/10.18293/SEKE2015-159

[6] Brian R. Fry and Jos C.N. Raadschelders. 2013. Mastering Public Administration: From Max Weber to Dwight Waldo. CQ Press.

[7] Lynn H. Crawford and Jane Helm. 2009. Government and governance: The value of project management in the public sector. Project Management fournal, 40. 1. 73-87. DOI: https://doi.org/10.1002/pmj.20107

[8] Holger Timinger. 2017. Modernes Projektmanagement: Mit traditionellem, agilem und hybridem Vorgehen zum Erfolg. John Wiley \& Sons.

[9] Ines Mergel. 2016. Agile innovation management in government: A research agenda. Government Information Quarterly, 33. 3. 516-523. DOI: https://dx.doi.org/10.1016/j.giq.2016.07.004

[10] C. J. Torrecilla-Salinas, J. Sedeño, M.J. Escalona and M. Mejías. 2013. Agile in Public Administration: Oxymoron or reality? An experience report. In CEUR Workshop Proceedings. Vol. 1017. 1-8.

[11] Anna Kaczorowska. 2015. Traditional and agile project management in public sector and ICT. 2015 Federated Conference on Computer Science and Information Systems (FedCSIS). IEEE. 1521-1531. DOI: https://dx.doi.org/10.15439/2015F279

[12] Teemu Lappi and Kirsi Aaltonen. 2017. Project governance in public sector agile software projects. International fournal of Managing Projects in Business. 10. 2. 263-294. DOI: https://doi.org/10.1108/IJMPB-04-2016-0031

[13] Jouko Nuottila, Kirsi Aaltonen and Jakkoo Kujala. 2016. Challenges of adopting agile methods in a public organization. International fournal of Information Systems and Project Management, 4. 3. 65-85. DOI: https://doi.org/10.12821/ijispm040304

[14] Sam Whimster and Scott Lash. 2014. Max Weber, rationality and modernity. Routledge.

[15] Renate Mayntz. 1978. Soziologie der öffentlichen Verwaltung. CF Müller Juristischer Verlag.

[16] Hellmut Wollmann. 2000. Local government modernization in Germany: Between incrementalism and reform waves. Public administration, 78. 4. 915936. DOI: https://doi.org/10.1111/1467-9299.00237

[17] Stephen P. Osborne (Ed.). 2010. The new public governance: Emerging perspectives on the theory and practice of public governance. Routledge.

[18] Torge Dyba and Torgeir Dingsøyr. 2008. Empirical studies of agile software development: A systematic review, Inform. Softw. Technol. DOI: https://doi.org 10.1016/j.infsof.2008.01.006 